\title{
Identification of Gastrointestinal Worms Egg on Spotted Deer (Axis axis) and Bawean Deer (Axis kuhlii) at Wonorejo Bibit Park and Surabaya Flora Park
}

\section{Identifikasi Telur Cacing Saluran Pencernaan pada Rusa Tutul (Axis axis) dan Rusa Bawean (Axis kuhlii) di Taman Flora dan Kebun Bibit Wonorejo Surabaya}

\author{
${ }^{1)}$ Achmad Hasan Sahani, ${ }^{2)}$ Sri Mulyati, ${ }^{3)}$ Tri Bhawono Dadi, ${ }^{4}$ Sri Mumpuni S, ${ }^{4)}$ Kusnoto, ${ }^{5}$ Ratna \\ Damayanti \\ ${ }^{1)}$ Student, ${ }^{2}$ Department of Veterinary Reproduction, ${ }^{3}$ Department of Veterinary Clinic, \\ ${ }^{4)}$ Department of Veterinary Parasitology, ${ }^{5}$ Department of Basic Veterinary Medicine. Faculty of \\ Veterinary Medicine, Universitas Airlangga.
}

\begin{abstract}
Abstrak
The purpose of this study was to identify the type of gastrointestinal worms egg of Spotted Deer (Axis axis) and Bawean Deer (Axis kuhlii) at Wonorejo Bibit Park and Surabaya Floral Park. The research was conducted in October-December 2017 used total 50 specimen of sample faeces, 40 sample faeces from Surabaya Flora Park and 10 sample faeces from Wonorejo Bibit Park, the samples analyzed at the Department of Parasitology Veterinary, Faculty of Veterinary Medicine, Airlangga University. The results showed that the degree of helmint gastrointestinal in Bawean Deer and Spoted Deer at Wonorejo Bibit Park showed o\% while at the Surabaya Flora Park is $15 \%$. The type of worm found were Trematoda class it was Fasciola sp. The resuls of the analysis used Chi-Square test and showed no significantly differences degree of gastrointestinal helminth infection ( $\mathrm{p}>0.05)$.
\end{abstract}

Key words: identification, gastrointestinal, helminth, Axis axis, Axis kuhlii

\section{Pendahuluan}

Rusa adalah satwa liar yang memiliki nilai estetika dan dapat dijadikan sebagai satwa pajangan dalam taman terutama rusa Tutul (Axis axis) dan rusa Bawean (Axis kuhlii). Hewan tersebut memiliki potensi ekonomi karena dapat menghasilkan kulit, velvet (tanduk muda) dan daging (Garsetiasih dan Takandjanji, 2006). Potensi yang dimiliki rusa mengakibatkan perburuan tidak terkendali, sehingga populasi rusa mengalami penurunan. Salah satu upaya dalam mengatasi penurunan populasi rusa adalah dengan membangun penangkaran.

Penangkaran rusa adalah usaha untuk memperbanyak populasi melalui pembesaran dan pengembangbiakan di luar habitat alami (ex-situ) dengan tetap mempertahankan kemurnian jenisnya (Takandjandji, 2008). Tetapi usaha penangkaran tidak lepas dari ancaman kegagalan akibat penyakit dikarenakan kondisi yang tidak sesuai dengan habitat aslinya, Salah satu masalah utama adalah parasit. Penyakit yang disebabkan oleh parasit helminth pada umumnya tidak menyebabkan kematian secara akut, tetapi bersifat kronis sehingga pada rusa dewasa akan mengakibatkan produksi dan kemampuan kerja yang menurun, sedangkan pada satwa muda akan menghambat pertumbuhan, nafsu makan menurun, anemia dan diare (Soulsby, 1986). Salah satu cara mendiagnosis keberadaan dari jenis parasit helminth dalam tubuh satwa adalah dengan pemeriksaan tinja segar (Rahmah dkk., 2013).

Informasi mengenai jenis parasit yang menginfeksi rusa di penangkaran dapat menjadi dasar yang mendukung kesuksesan usaha penangkaran satwa liar. Data ini selain dapat digunakan sebagai bahan untuk menentukan pengambilan kebijakan tindakan medik terhadap satwa penangkaran, juga dapat sebagai bahan acuan untuk mengetahui potensi patogenitas 
parasit baik pada hewan dan manusia mengingat banyak jenis parasit yang bersifat zoonosis (Nugroho dan Purwaningsih 2015).

\section{Metode Penelitian}

Pengambilan sampel dilakukan di Kebun Bibit Wonorejo dan Taman Flora Surabaya, sedangkan pemeriksaan sampel feses dilakukan di Laboratorium Departemen Parasitologi Fakultas Kedokteran Hewan Universitas Airlangga. Penelitian ini dilaksanakan pada Bulan Oktober sampai Desember 2017.

Penelitian ini menggunakan total 50 sampel feses yang terdiri dari 20 sampel feses rusa Tutul dan 20 sampel feses rusa Bawean yang diambil dari Taman Flora, serta kemudian 7 sampel feses rusa Tutul dan 3 sampel feses rusa Bawean yang diambil dari Kebun Bibit Wonorejo Surabaya.

Analisis statistik dengan rumus Chi-Square dengan menggunakan progarm IBM SPSS Statistics versi 23 untuk mengetahui tingkat perbedaan (antara lokasi Kebun Bibit Wonorejo dan Taman Flora Surabaya) terhadap infeksi cacing saluran pencernaan.

\section{Hasil dan Pembahasan}

Hasil pemeriksaan, sampel feses rusa Tutul (Axis axis) dan rusa Bawean (Axis kuhlii) di Taman Flora Surabaya ditemukan hasil positif mengandung telur cacing sebanyak $15 \%$ dari total sampel, sedangkan pada Kebun Bibit Wonorejo tidak ditemukan sampel feses yang positif. Pada pemeriksaan morfologi telur cacing dari semua sampel yang positif hanya ditemukan telur cacing dari kelas Trematoda yaitu Fasciola sp. Hasil identifikasi ditemukannya telur cacing saluran pencernaan pada rusa Tutul dan rusa Bawean di Taman Flora dan Kebun Bibit Wonorejo Surabaya dapat diketahui pada Tabel 1

Tabel 1. Persentase telur cacing saluran pencernaan pada rusa Bawean dan rusa Tutul Kebun Bibit Wonorejo dan Taman Flora Surabaya

\begin{tabular}{cccc}
\hline Lokasi & Positif & Negatif & Jumlah \\
\hline TFS & $6(15 \%)$ & $34(85 \%)$ & $40(100 \%)$ \\
KBW & $0(0 \%)$ & $10(100 \%)$ & $10(100 \%)$ \\
& $6(12 \%)$ & $44(88 \%)$ & $50(100 \%)$ \\
\hline $\begin{array}{l}\text { TFS : Taman } \\
\text { Wonorejo }\end{array}$ & Flora Surabaya, KBW & : Kebun Bibit \\
\end{tabular}

Hasil tabulasi silang menunjukkan adanya perbedaan ditemukannya telur cacing saluran pencernaan sebesar $15 \%$ untuk di Taman Flora Surabaya dan o\% untuk rusa di Kebun Bibit Wonorejo. Pada analisis statistik menggunakan metode Chi-Square diperoleh nilai signifikasi sebesar o,446 yang menunjukkan tidak adanya perbedaan yang nyata ( $\mathrm{p}>0,05)$.

Hasil pemeriksaan hanya ditemukan satu jenis telur cacing dari kelas Trematoda yaitu Fasciola sp,sedangkan telur cacing dari kelas Nematoda dan Cestoda tidak ditemukan. Hal ini dimungkinkan karena cacing saluran pencernaan yang lain masih dalam keadaan stadium larva, belum dewasa atau telur cacing terlalu sedikit dan tidak homogen dalam feses, sehingga pada pemeriksaan feses telur cacing tidak ditemukan (Wirawan dkk., 2006).

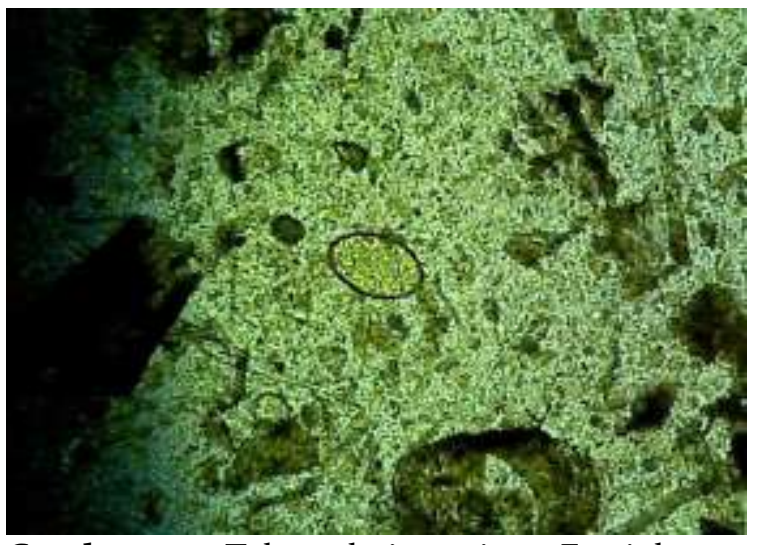

Gambar 1. Telur dari cacing Fasciola sp. (Perbesaran 100x).

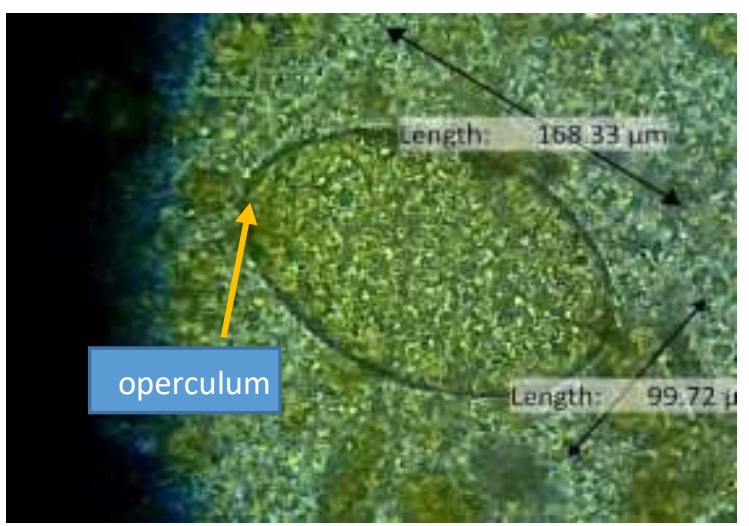

Gambar 2. Telur dari cacing Fasciola sp. (Perbesaran 400x). 


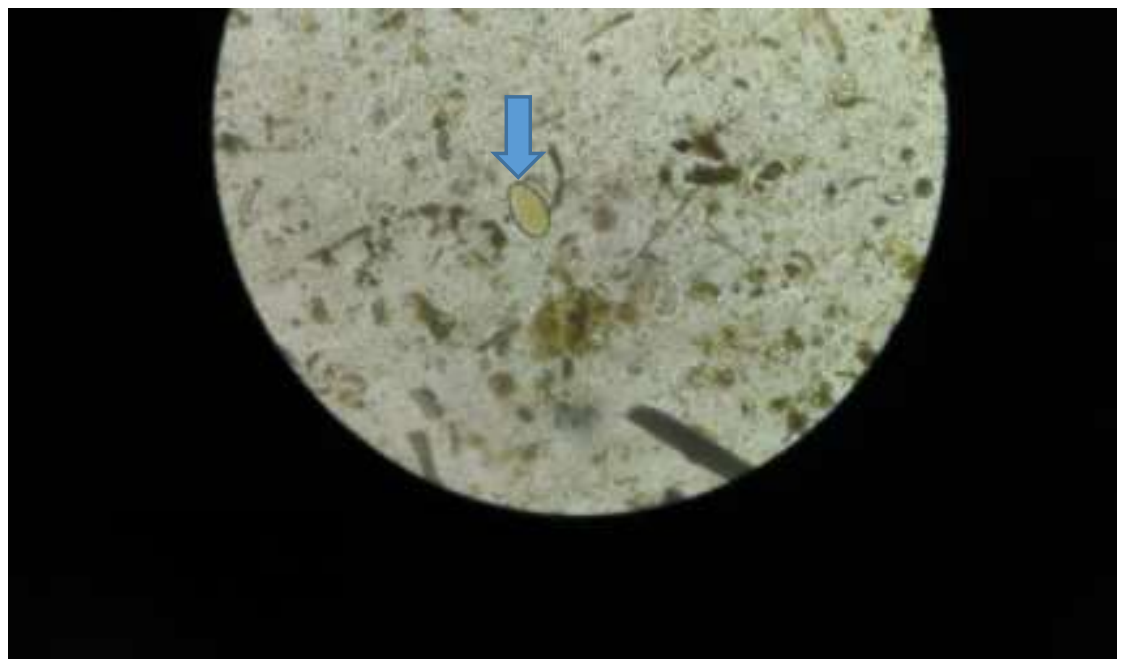

Gambar 3. Telur dari cacing Fasciola sp. (Perbesaran 100x).

Sedangkan adanya infeksi dari Fasciola sp dimungkinkan karena rusa memakan stadium infektif pada pakan rumput atau minuman yang terkontaminasi oleh metacercaria. Pada penelitian ini Rusa Bawean dan rusa Tutul di Taman Flora Surabaya memiliki tingkat infeksi sebesar $15 \%$ sedangkan rusa di Kebun Bibit Wonorejo memiliki tingkat infeksi o\%.

Perbedaan terhadap teridentifikasinya telur cacing saluran pencernaan pada rusa Tutul dan rusa Bawean di Kebun Bibit Wonorejo serta Taman Flora Surabaya dapat disebabkan beberapa faktor, salah satunya lewat pakan yang tercemar larva infektif. Subronto dan Tjahajati (2001) menyebutkan bahwa kebanyakan jenis parasit saluran pencernaan yang masuk ke dalam tubuh hospes definitif melalui mulut dari pakan yang tercemar. Dalam memenuhi kebutuhan pakan harian, petugas di Taman Flora memberikan pakan tambahan rumput yang berasal dari daerah tanah lapang yang luas dekat daerah rawa. Hal ini di sebabkan oleh banyaknya jumlah populasi rusa. Berbeda dengan rusa di Kebun Bibit Wonorejo yang hanya berjumlah 10 ekor yang mendapatkan pakan dari hijauan di sekitar kebun tersebut dengan tingkat resiko kontaminasi metacercaria yang minim.

\section{Kesimpulan}

Penelitian identifikasi telur cacing saluran pencernaan pada rusa Tutul dan rusa Bawean di Taman Flora dan Kebun Bibit Wonorejo Surabaya dapat disimpulkan bahwa ditemukan telur cacing
Fasciola sp. pada feses rusa Tutul dan rusa Bawean di Taman Flora Surabaya, sedangkan pada sample feses rusa Tutul dan rusa Bawean di Kebun Bibit Wonorejo tidak ditemukan telur cacing.

\section{Daftar Pustaka}

Garsetiasih R dan M Takandjandji. 2006. Model penangkaran rusa. Dalam: Konservasi dan Rehabilitasi Sumberdaya Hutan. Prosiding Ekspose Hasil - Hasil Peneltian; Padang 20 September 2006. Bogor: Pusat Penelitian dan Pengembangan Hutan dan Konservasi Alam, Departemen Kehutanan.

Mumpuni, S., S. Subekti, S. Koesdarto dan Kusnoto. 2016. Penuntun Praktikum Ilmu Penyakit Helminth Veteriner. Fakultas Kedokteran Hewan Universitas Airlangga. Surabaya.

Nugroho HA, Purwaningsih E. 2015. Nematoda parasit gastrointestinal pada satwa mamalia di penangkaran Pusat Penelitian Biologi LIPI Cibinong, Jawa Barat. Pros Sem Nas Masy Biodiv Indon 1: 1785-1789.

Rahmah, F., Dahelmi dan Salmah, S. 2013 Cacing Parasit Saluran Pada Hewan Primata di Taman Satwa Kandi Kota Sawahlunto Provinsi Sumatra Barat. Jurnal Biologi Universitars Andalas 2: 14-19. 
Soulsby, E. J. L. 1986. Helminth, Arthropods and Protozoa of Domisticated Animals $7^{\text {th }}$ Bailliere, Tindal and Cassel, London.

Subronto dan I. Tjahajati. 2001. Ilmu Penyakit Ternak II. Gadjah Mada University Press. Yogyakarta.

Takandjandji, M. 2008. Teknik Penangkaran Rusa Timor (Rusa Timorensis Blainville, 1822).
Wirawan, I.G.K.O, R.W. Nurcahyo dan J.Prastowo. 2006. Kejadian Strongyloidiasis dan Fasciolasis pada Rusa Bawean (Axis kuhlii) dalam hubungan dengan Infeksi Cacing Gastrointestinal pada Ternak Ruminansia di Pulau Bawean. Program Studi Sains Veteriner. Universitas Gadjah Mada. Yogyakarta. 369-380. 